\title{
The construction of ergonomic demands: application on artisan fishing using jangada fishing rafts in the beach of Ponta Negra
}

\author{
Maria Christine Werba Saldanha*, Ricardo José Matos de Carvalho, Larissa Praça de Oliveira, Joyce \\ Elanne Mateus Celestino, Isis Tatiane de Barros Macêdo Veloso and Anelena Jaeschke \\ UFRN- Federal University of Rio Grande do Norte, Technology Center, Production Engineering Programme- \\ PEP, Campus Universitário, Room 48, CEP: 59.072-970, Lagoa Nova, Natal, RN, Brazil. Tel/fax: + 55 (0xx84) \\ 8770-7861
}

\begin{abstract}
The present article seeks the process of construction of ergonomics demand referring to the artisan fishing activityfound in Ponta Negra beach located in the city of Natal, Brazil. The instruction/construction of demands correspond to the first stage of Work Ergonomic Analysis and allows the understanding of real issues existent in a work situation, rank them and route the providences. The demand presented on this study, features itself as a induced demand, process which some potential demands or hypothetical demands are taken to an organization, after a preview analysis of the work aimed by the study, resulting from a theoretical research (state of the art) and/or from analysis of a reference situation (state of practice), where demands hypothesis are taken in consideration about the pretended work. The demands construction process using interactional methods and techniques, observation methods and techniques and bibliographic research, researches in state of reference or document. This article demonstrates the efficiency of the methodological choice to construct real ergonomic demands and highlights the importance of social construction on that process, which main goal is to refer the ergonomic actions that allow the improvement of work and life conditions for the fishers and sustainability to Jangadeira activity.
\end{abstract}

Keywords: demand construction, social construction, ergonomics, artisanal fishery; rafts

\section{Introduction}

The artisanal fishery is the one which enables itself by fisher's handmade labor, using boats and capture of marine animals in small-scale, with commercial and/or subsistence. Due capture scale, the environmental impacts on the fishing resources generated from that kind of fishery do not happen with the same intensity of industrial fishery $[12,13]$. The artisanal fishery done with rafts is one traditional and peculiar characteristic of Brazilian northeast, marked by unpredictability, risk, accidents and incidents, precarious conditions of work and hygiene and low financial return. In the state of Rio Grande do Norte, Brazil, that activity is held by several costal communities with the finality of subsistence and commercialization. According statistics data from the superintendence of Brazilian institute of environment and natural renewable resources (in his Portuguese abbreviation) [7], That modality of fishery represents around $12,10 \%$ of the annual volume of fish in Rio Grande do Norte.

This article limits itself to show how was the the implantation of the construction demands process, as a part of the project of research and extension, titled raft activity: tradition, ergonomics and sustainability by GREPE -UFRN in Ponta Negra beach, Natal-RN, Brazil [10]. The ergonomic analysis of rafter's work of Ponta Negra beach and the group of ergonomic actions have taken part on the project, that aimed to model a work activity from the jangadeiros who practiced artisanal fishery in Ponta Negra Beach, on the of characterize the jangadeira activity and understand how technical, human, environmental and social factors coexisting in work situations interfere or determine the specific activities of fishers.

\footnotetext{
* Corresponding author e-mail: cwerbasaldanha@gmail.com
} 
The instruction/construction of ergonomic demands correspond to the first stage of an Work Ergonomic Analysis-WEA [15-16-6-14-9,3] and allows the understanding of real issues occurred in work situations, particulary, artisinal fishery, using rafts, with fishers from Ponta Negra.

In the demand construction process [9], the signaled beginning of the ergonomic action is the Induced Deman, in other words, a group of hypothesis of demands formulated from the resurgence of theoretical reference and/or situation reference [2-3-9,14] in the taken activity.

The hypothesis of demands shall be demonstrated considering the data available and supported by a social construction process, namely, structuring of a team who will enable an ergonomic action. That team includes people that shall compound the staff of ergonomic action in many ergonomic intervention moments, directly correspondent to action, technical support and decision or to the people who participate on the collection of information.

\section{Methodology}

The construction of demand process [9,3] was based on the method of Work Ergonomic AnalysisWEA [15-16-6,14]. The WEA is a group of analysis which are global, systematic and mutual complementary, promoting a operating model of work situation, in other words, the modeling of real activity in the context, considering technical, human, social and environmental aspects [14], following these steps: Instruction/construction of demands, modeling and project of activity, and construction of solutions.

The construction of demands came from promoted demands and the process of social construction sustained it [2-3-5-9,3], using interactional methods and techniques (conversational action, scope of spontaneous and caused verbalizations), through the application of dynamic scripts and socio-economical questionnaires and observational methods and techniques (systematic observations aided by films and photography) [14], both for focus situation or reference situation [4] considered, bibliographic and documentary research.

\section{Results}

\subsection{Artisanal fishery with rafts in Ponta Negra Beach}

The artisanal fishery with rafts in Ponta Negra beach in Natal-RN is developed by forty-two male fishers, age group predominant of forty-one to fifty years old, incomplete first grade and with the average from three to seven children per men. From the sample (composed by forty-two fishers), 69\% confirmed that they had or have other type of job besides fishing,o complement their income.

Some of them have license to fish lobster and receive a minimum wage during the time of closure (december to may), used for the acquisition of food, and investments as necessary equipment and utensils for the fishing and the rafts. Most of the fisher lives at Vila de Ponta Negra, an area localized approximately 850 meters from the anchoring of the rafts. Some of them have license to fish lobster and receive a minimum wage during the time of closure (december to may), used for the acquisition of food, and investments as necessary equipment and utensils for the fishing and the rafts. Most of the fisher lives at Vila de Ponta Negra, an area localized approximately 850 meters from the anchoring of the rafts.

The rafts of Ponta Negra, called paquetes, are medium, according to Araújo's classification [1]. They are built naval plywood and wood, measuring about 4 to 5 meters of length and 1.4 to 1.7 meters of width, they have sail and/or engine propulsion and usually support two or three people as crew (master and helpers) that play different functions.

The fishery occurs from Tuesday to Saturday. The predominant kind of fishery is with a net, becoming common a net fishing, in the gap between 30 and 60 minutes that the fishers wait, to pull the net once released in the sea. The work strategy of fishers' work is straightly connected to type of fishery in course: the "ida e vinda" and the "gelo". On the "ida e vinda" fishery, which takes about 8 hours, the fishermen go out to the sea early morning, returning in the morning, or they go I the afternoon and come back at night, depending on tide condition, lunar fase, months of the year and weather conditions. On "gelo" fishery, which is stocked with ice to the preservation of fish, usually, fishermen go to sea in the beginning of the morning and can spend 24 hours fishing. 
For the setting of the fishery, the masters use as points of reference the hills and city buildings, which are displayed from the raft. The access to the ocean follows the conditions of the tides, lunar phases, the months of the year and weather conditions. The decisions are taken from the tacit knowledge acquired during their experience and expertise in the activity, showing the know-how typical of these workers. This knowledge is often overlooked by fishermen when they decide to hold expeditions to capture in adverse weather conditions, driven by the pressing need of support and feeding.

The capture expedition begins with the preparations at the residence of the fishermen, where they exit towards the Ponta Negra beach carrying with them: food, tools and instruments needed to perform the activity. Once they are in the place where the rafts are moored they start the organization and checking process on the raft . Then the manual displacement proceedings of the rafts are performed until they get in the ocean, using two rolls of coconut tree and cooperation of other fishermen and other roleiros. The raft is then directed, the crew come up and begin their specific procedures for navigation according to the chosen method of propulsion, sail or engine Arriving at the fishing, the fishermen cast their nets into the sea, wait for the necessary time and collect their nets, and stock the fish in particular devices, the nets are stocked in a internal compartment on the raft. Depending on the outcome of the fishery, this procedure may be repeated in the same place or in another fishing. After those procedures, the crew perform the navigation returning to Ponta Negra beach, where, after they perform the withdrawal procedures, docking and organization of the raft, commercialize the fish and return to their homes where they rest until the next capture expedition or other activity linked to fishing. Figure 1 shows a schematic representation of the capture expedition with rafts

Figure 1:

Capture expedition in the raft activity in Ponta Negra, Natal-RN

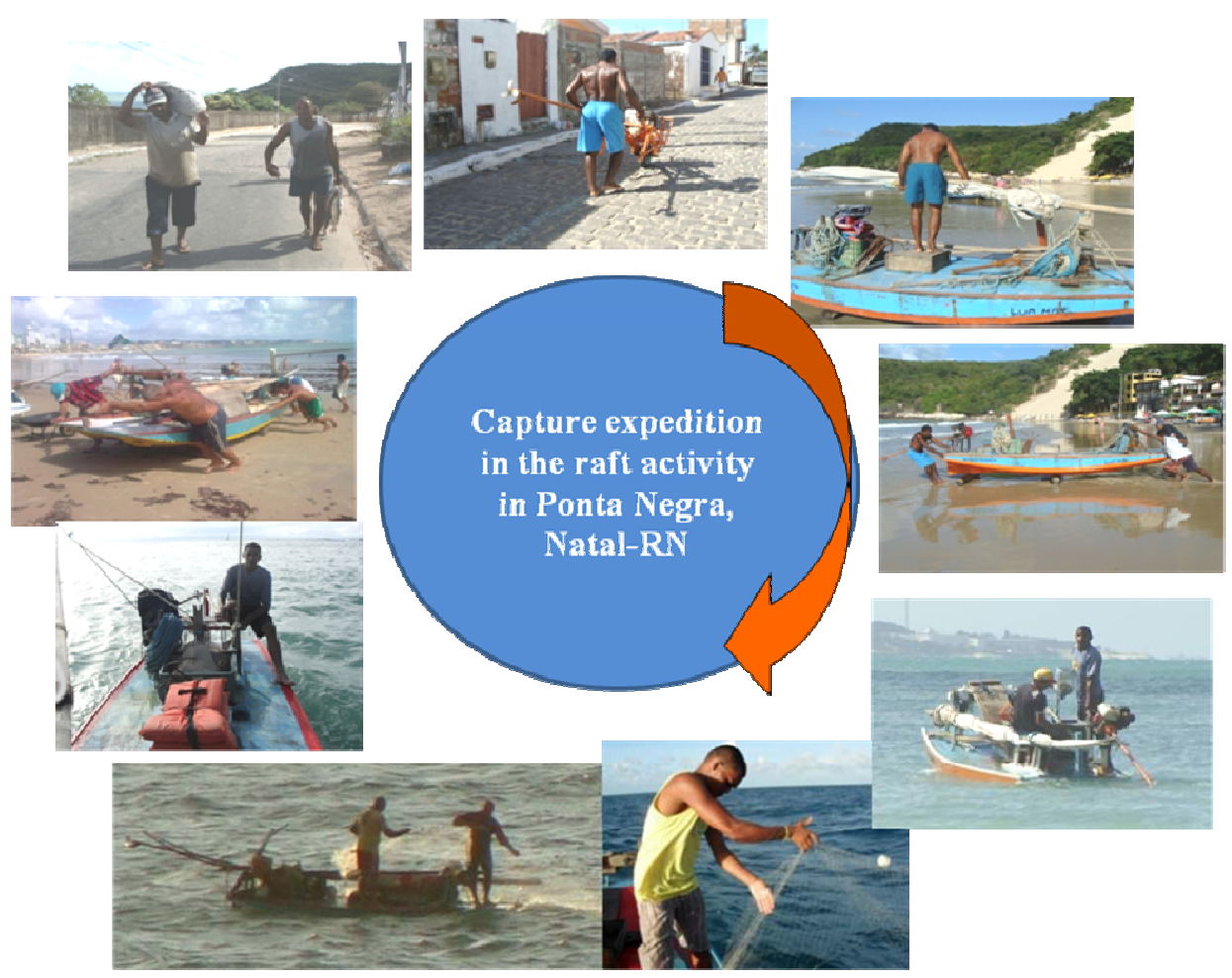


Table 1

\subsection{Social construction in the demands construction on the raft activity}

The Social Construction (SC) is a participatory action structure, technical and management which is made from the stage of instruction / construction of the demand in an ergonomic action. The SC is composed per groups of people who are involved directly or indirectly, in the work situation, participating in the informational survey and/or their refunds and validations allowing to know about the activity analysis and implementation of improvements [14,9].

On the present study, the social construction was developed from the analysis of reference situations (Areia Preta and Redinha, urban beaches located in Natal ), previous technical visits made in institutions related to fishing industry and in Ponta Negra Beach. This process allowed identification of interlocutors and constituent of the groups who cooperated with the research and provided the necessary information for understanding the activity and promotion of improvements. Figure 2 below, shows the technical drawing of the social construction devide, with the respective groups already involved in this project.

\section{Figure 3}

Technical drawing of the divice for social constrution of ergonomic action in raft activity. [14-9,3] (adapted),

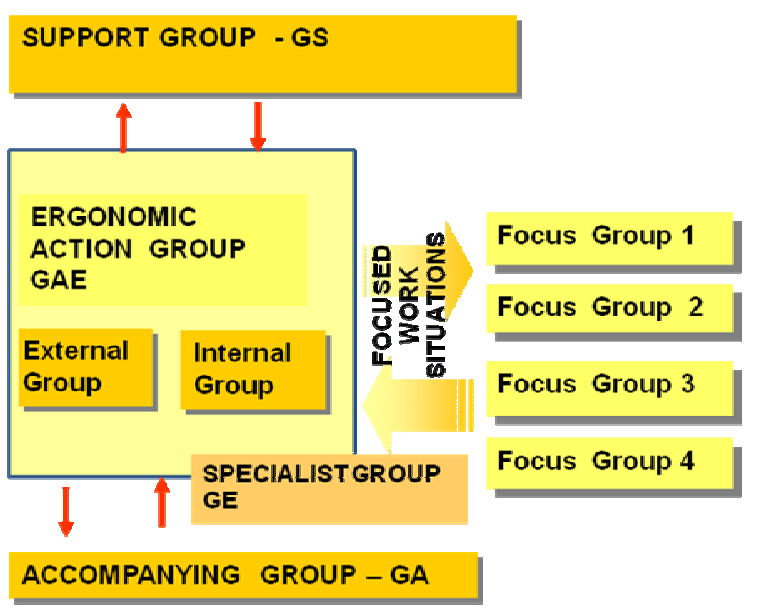

The table 1 illustrates the composition and the function of each group the technical drawing of the social construction
Characteristics of social construction groups

\begin{tabular}{|c|c|}
\hline Groups & Characteristics \\
\hline $\begin{array}{c}\text { Ergonomic } \\
\text { Action } \\
\text { Group } \\
\text { GAE }\end{array}$ & $\begin{array}{l}\text { Formed by the articulation between the } \\
\text { External Group (multidisciplinary group } \\
\text { with the knowledge on the concepts, tech- } \\
\text { niques and methods of ergonomics and also } \\
\text { the specific knowledge on the acting áreas of } \\
\text { the Project such as: aquiculture, physiothe- } \\
\text { rapist, nutritionist, designer, environment } \\
\text { technician, engineer) and the Internal Group } \\
\text { (jangada fishermen representative, privileged } \\
\text { interlocutor in charge of the External Group } \\
\text { articulation with the fishermen community). }\end{array}$ \\
\hline $\begin{array}{l}\text { Support } \\
\text { Group } \\
\text { GS }\end{array}$ & $\begin{array}{l}\text { Formed by people who can make decisions } \\
\text { in the work situation ( President of the fi- } \\
\text { shermen colony and fishermen representa- } \\
\text { tive) and by those involved in the research } \\
\text { group (Project coordinator) }\end{array}$ \\
\hline $\begin{array}{c}\text { Accompanying } \\
\text { Group } \\
\text { GA }\end{array}$ & $\begin{array}{l}\text { Formed by people who have technical au- } \\
\text { thority to take technical decisions related to } \\
\text { the fishing activity (some master fishemen } \\
\text { and Carpenters) and to the research (research } \\
\text { coordinator/advisor. }\end{array}$ \\
\hline $\begin{array}{l}\text { Specialist } \\
\text { Group } \\
\text { GE }\end{array}$ & $\begin{array}{l}\text { Formed by people to whom the GAE reccurs } \\
\text { in order to treat specific subjects in some } \\
\text { áreas and also those who are co-advisors of } \\
\text { the research and/or specialist in the acting } \\
\text { fields of the project. }\end{array}$ \\
\hline $\begin{array}{l}\text { Focus } \\
\text { Group } \\
\text { GF }\end{array}$ & $\begin{array}{l}\text { Formed by people who participate actively } \\
\text { in the collecting of data, restitions and vali- } \\
\text { dation. Master fishermen and assistants, } \\
\text { carpenter, fishmongers and people employed } \\
\text { by the fishing related institutions. }\end{array}$ \\
\hline
\end{tabular}

\subsection{Demands construction in raft activity in Ponta Negra}

The demand presented in this study was characterized as an induced demand,according to the set of demands led to an organization, from a theoretical research(state of the art) and / or research in in an reference situation (state of practice)considered, where some demand hypothesis are raised on the aim of our project. Hypothesis are intuitive statements that should be demonstrated considering the data available and/or collected in the field. [14].

The scheme of demand construction process can be observed in Figure 3. 
Figure 3

Scheme of ergonomic demand construction negotiated in raft activities.

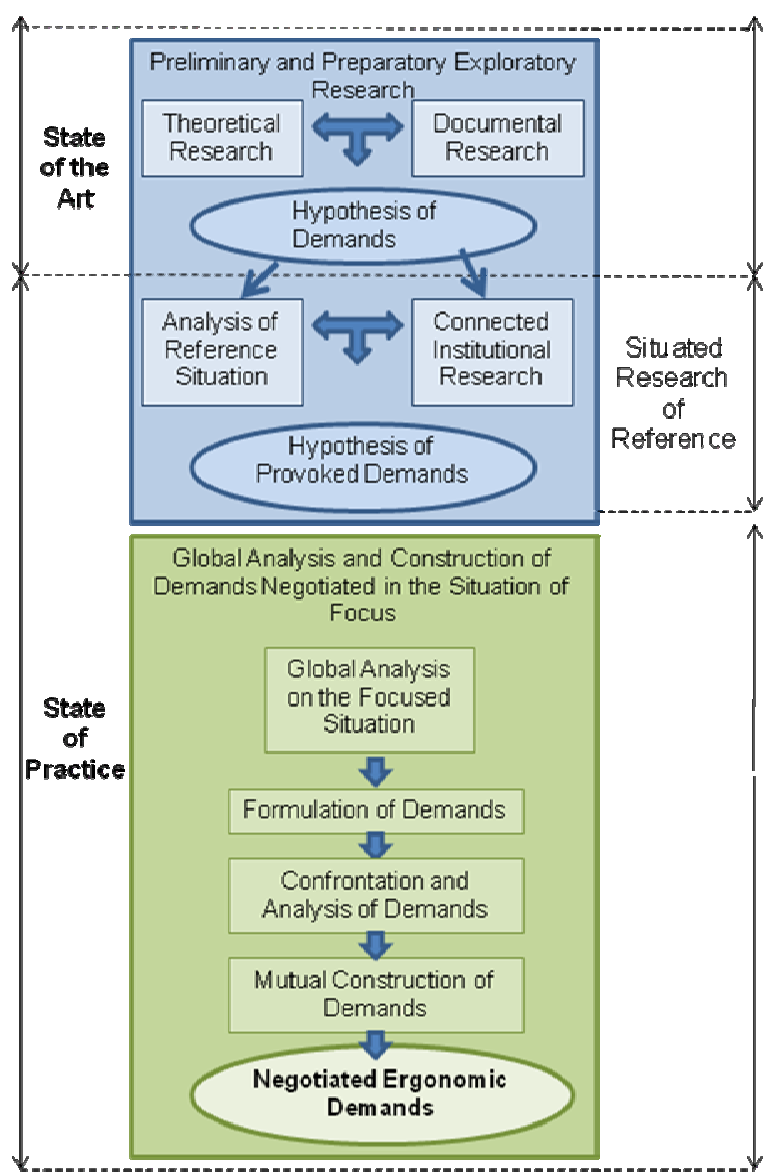

\subsubsection{Art state}

It refers to what was possible to collect about fishing with rafts, through theoretical and documental research related This study would enable the first chance to to rise the primary hypothesis of research and intervention, in other words, the first hypothesis of ergonomic demands that would guide the state of ergonomic practices or actions.

\subsubsection{Practice state}

The state of practice corresponded to surveys conducted in reference situations [4], work situations that had similar characteristics to the focus situation, which enabled the establishment of demands that would be caused in the focus situation .

The analysis in reference situations relate the activities of rafts fishery made in two urban beaches of
Natal (Areia Preta and Redinha). To this end, there were 14systematic visits ( 9 in Areia Preta and 5 in Redinha) using observational and interactional techniques aided by photographic and video records. In reference situations was possible to identify conditions with similar characteristics to the situation of focus (Ponta Negra beach), facilitating the understanding of the activities of fishermen and their context. In addition, research in the reference situation, as highlighted by [9], allowed the knowledge of common operating reference constituted by contextual information, for the specific language of the sector and the shared knowledge that formed the basis for cooperative exchanges that occurred throughout this intervention - research project. In this sense, the reference analysis produced essential knowledge needed for both the development of research tools, and for the support of conversational action at decisive moments of social construction of the demand on the situation.

\subsubsection{Connected institutional researches}

The complementary researches in governmental and non-governmental organizations related to fishing activity, aimed to clarify some demands highlighted in the literature, as well as raise the possible institutional demands related to the fishermen activity. This research took place at the following institutions: the Port of Rio Grande do Norte, Z-04 Cologne of Fisheries and Aquaculture of Natal, Special Secretariat of Aquaculture and Fisheries of Natal (SEAP), Defense Institute of the Environment (IDEMA), Brazilian Institute of Environment and Renewable Natural Resources (IBAMA),Fishermen's Hospital, Reference Center for Occupational Health (CEREST),Federation of Fishermen of Rio Grande do Norte. Actions were carried out in those institutions, conversational and documentary researches, and participation in courses and events related to fishing.

\subsubsection{Hypothesis of Induced Demand}

After careful analysis of the rised information since the art and practice state, it was possible to formulate the hypothesis of induced demand, as shown in Table 2.

\subsubsection{Global analysis of the focused situation- Ponta Negra Beach}


Global analysis corresponds to an macro analysis of the work activity, essential to clarify the ergonomic demands [14]. For the overall analysis on the Ponta Negra, 20 were carried out systematic visits from April to July 2009, using interactional methods and techniques (conversational action, listen to caused and spontaneous verbalizations), scripts and dynamic socio-economical survey and, observational methods and techniques (aided by open observations by films and photos)

The global analysis enabled the knowledge of the population (42 fishermen), understanding the activity in its context, evidence of some of the demands and the hypothesis of identifying latent and the fishermen, particularly in the situation in focus.

\subsubsection{Formulation and selection of ergonomic demandsch}

The formulation of demands started from the confrontation between the hypothesis (state of the art and practice) and the induced demands of the situation , Ponta Negra beach(Table 2). The formulation of demands started from the confrontation between the hypothesis (state of the art and practice) and the induced demands of the situation, Ponta Negra beach (Table 2).

Table 2

Confront of demands in raft activity

Demands of Fishing Activity Origin

\begin{tabular}{|c|c|}
\hline Demands of Fishing Activity & Origin \\
\hline \multicolumn{2}{|l|}{ Health } \\
\hline Physical and mental overload & $\bullet$ \\
\hline Work overtime & $\bullet$ \\
\hline Neuromuscular and joint pains & $\bullet$ \\
\hline $\begin{array}{l}\text { Infectious diseases and non-communicable diseases } \\
\text { (eye problems, diabetes) }\end{array}$ & $\bullet$ \\
\hline $\begin{array}{l}\text { Diet inadequate for the activity with low consump- } \\
\text { tion of fruit and vegetables }\end{array}$ & $\bullet$ \\
\hline $\begin{array}{l}\text { Inadequate manipulation of food and contamination } \\
\text { of water and food(gastroenteritis) }\end{array}$ & $\bullet$ \\
\hline $\begin{array}{l}\text { Fishermen posture when cutting sardine baits on the } \\
\text { boat; }\end{array}$ & $\bullet$ \\
\hline $\begin{array}{l}\text { Fishermen posture when setting the mast in high sea; } \\
\text { pulling the anchor }\end{array}$ & $\bullet \boldsymbol{\Delta}$ \\
\hline $\begin{array}{l}\text { Physical Power to turn/pull/push the jangada raft; } \\
\text { how to throw water at the sail; }\end{array}$ & $\bullet \boldsymbol{\Delta}$ \\
\hline Removing sea fishing nets & $\Delta$ \\
\hline \multicolumn{2}{|l|}{ Safety } \\
\hline Precarious work tools & $\bullet$ \\
\hline Adverse weather conditions & $\bullet$ \\
\hline Lesion occurrences & $\bullet$ \\
\hline $\begin{array}{l}\text { Absence of financial conditions to aquire } \\
\text { salvage equipment; }\end{array}$ & $\bullet$ \\
\hline
\end{tabular}

\begin{tabular}{|c|c|}
\hline Not following Marine norms & $\bullet \Delta \Delta$ \\
\hline Accident risk for bathers; & $\Delta \Delta$ \\
\hline Difficulty to move the raft (dependency of wind); & 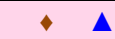 \\
\hline Reduced space and bad habitability & $\bullet$ \\
\hline \multicolumn{2}{|l|}{ Fish Handling } \\
\hline Inadequate handling of fish & $\bullet$ \\
\hline Inadequate cleaning of boats & $\bullet \Delta$ \\
\hline \multicolumn{2}{|l|}{ Environment } \\
\hline Pollution and lack of environmental awareness & $\bullet$ \\
\hline Fall in fish production; & 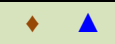 \\
\hline \multicolumn{2}{|l|}{ Management } \\
\hline $\begin{array}{l}\text { Importance of registering at the Z4 Colony of aqui- } \\
\text { culture and Fishing in Natal. }\end{array}$ & $\Delta \boldsymbol{\Delta}$ \\
\hline Authorization for lobster fishing; & $\Delta$ \\
\hline $\begin{array}{l}\text { Absence of record and control on the number of } \\
\text { active fishermen. }\end{array}$ & - \\
\hline
\end{tabular}

situation $\diamond$; Iinstitutions $\square$, Focus situation $\Delta$

The refund of collected information and validation of fisherman demands in the community was held in a meeting with members of Focus Groups 1, 2 and 3 (master fishermen, helpers and builder - carpenter of raft), Support and Monitoring, allowing the confirmation of demands, which were grouped according to the following classification, as nature: health, safety, handling of fish, raft design and environment (Table 3).

Table 3

Demands of raft activities in Ponta Negra, Natal Brazil

\begin{tabular}{c|l}
\hline \multicolumn{1}{c}{ Ergonomic demands } \\
of the fishing activity in Ponta Negra Beach
\end{tabular}




\section{Analysis and discussions}

The search for effective ergonomic solutions and positive transformation of work situations starts with the demand construction process, ie, identifying the demands of a real work situation. This process becomes more efficient when it counts the participation of the various subjects involved, the expertise and tacit knowledge and takes into account the contexts.

It was observed that $73.68 \%$ of the cases related to hypothesis of induced demands, identified through theoretical research (state of the art) and the reference situations (state of practice) were confirmed on the focus situation.

Regarding the demands of fishermen, it was observed that $29 \%$ of these are related to the health of fishermen, $29 \%$ are related to safety, 21 to the environment $\%, 14 \%$ are linked to the effectiveness of capture, and the $7 \%$ include aspects of management of fishermen activity (fishermen interrelationship with the institutions related to fishing).

The construction of demands sustained by social construction and justified by the Work Ergonomic Analysis, emerged as an appropriate methodological process, as it had an fundamental methodological condition, the participation of the staff directly involved in fishing activity in focus and aimed at clarifying the real demands of a situation that does not always correspond to the representation of managers' demands from research funding agencies and / or groups of research and extension.

More than a list of actual demands, the results presented here pointed to the need for the creation and deepening of specific public politics and implementation of a program of public actions by government (municipal, state and federal) specific, bringing together institutions of credibility and expertise in the social sector, economic (financing, production, logistics and sales), cultural, ecological and fishing, with the direct participation of fishermen and their communities, to leverage and consolidate the sustained activity of artisanal fishing and raft in Natal.

Accustomed to working with business organizations, the university, through this project, experienced, and is demonstrating through this article, that is possible to cooperate with the genuine demands of the communities and that communities, like the fishermen community of Ponta Negra beach, may be an actual development site for research, production of knowledge and practical action in the scientific and technical body of university, and as a methodological principle, the participation of the subjects from community interest and mutually respectful interaction.

The scientific findings and the ergonomic actions arising from this Project have been contributing to preserve and prosper the secular and traditional activity of artisanal fishing with rafts in Ponta Negra, that heroically sub-exists in contemporary times, thanks to the actions of mobilization of your community, that may have faced as the absence of effective government incentives, the threat of uncontrolled tourism, the unbalanced growth of the estate industry and the actions of environmental degradation that reflects in the economy of artisanal fishery, which has a great importance for the city's economy and the development, in the meaning of feeling the belonging of the fishermen in relation to the place they live and produce, Ponta negra beach and the community of Vila de Ponta Negra, as Rio Grande do Norte as a whole. [17]

\section{References}

[1] Araújo, N.B.G. Jangadas. Fortaleza, Banco do Nordeste do Brasil S.A., 1985.

[2] Carvalho, R.J.M, Saldanha,M.C.W. Relatório de Instrução da Demanda. CESERG,GENTE/COPPE/UFRJ, 2001.

[3] Carvalho, R.J.M.de. A padronização situada como resultante da ação ergonômica em sistemas complexos: estudos de caso numa companhia aérea nacional a propósito da implantação de um treinamento CRM-LOFT. Tese (Doutorado em Engenharia de Produção). Rio de Janeiro: COPPE/UFRJ, 2005.

[4] Daniellou, F. Métodos e ergonomia de concepção: a análise de situações de referência e a simulação do trabalho. In: Duarte, Francisco. Ergonomia e projeto na indústria de processo contínuo. Rio de Janeiro: COPPE/UFRJ: Lucerna, 2002, p.29.

[5] Daniellou, F. A ergonomia em busca de seus princípios: debates epistemológicos. São Paulo: Edgard Blucher, 2004 $244 \mathrm{p}$.

[6] Guérin, F. et al.. Compreender o trabalho para transformá-lo: a prática de ergonomia. São Paulo: Edgard Blucher LTDA. 2001. $195 \mathrm{p}$.

[7] IBAMA-RN. Boletim Estatístico da Pesca Marítima e Estuarina do Estado do RN -2007- Natal - ABRIL/2008.

[8] Marques, F.R.. Uma visão contextual da pesca comercial: sobrepesca e estatística de produção pesqueira em Cabo Frio RJ In: O Trabalho da Pesca: Segurança, Saúde e Integração. Rio de Janeiro: Pro Uni-Rio / Unilagos..2000. 61 p.

[9] Saldanha, M.C.W. Ergonomia de concepção de uma plataforma Line Oriented Flight Training (LOFT) em uma companhia aérea brasileira: a relevência do processo de construção social de projeto. 236f. Tese (Doutorado em Engenharia de Produção) - Universidade Federal do Rio de Janeiro, COPPE/UFRJ, 2004.

[10] Saldanha, M.C.W. Projeto Jangadeiros: tradição, ergonomia e sustentabilidade. Projeto de Pesquisa e Extensão. GREPE/UFRN. Natal-RN, 2007

[11] Saldanha, M.C.W, Carvalho, R.J.M.; Oliveira, L.P. Celestiono, J.E.M. Ergonomia e Sustentabilidade na Atividade Jangadeira: Construção das Demandas Ergonômicas 
na Praia de Ponta Negra-RN. In: Anais do ERGOMAR, Congresso de Ergonomia nas Atividades Marítimas e Costeiras, Cabo Frio-RJ-Brasil, 2010, 20p.

[12] Santos, T. C. C., Câmara, J. B. D. Geo Brasirquivo= $395>$ Acesso em 14 set. 2008

[13] Silva, S. M. M. C. Caracterização da Pesca Artesanal na Costa do Ceará, BRASIL. Tese (Doutorado em Biologia e Recursos Naturais). São Paulo: Centro de Ciências Biológicas e da Saúde. UFSCAR. 2004. 262 p. Disponível http://www.bdtd.ufscar.br/tde_busca/arquivo.php?codArquivo $=395>$ Acesso em 14 set. 2008 .

[14] Vidal, M.C. Guia para Análise Ergonômica do Trabalho na empresa: uma metodologia realista, ordenada e sistemática. Rio de Janeiro: Virtual Científica. 2003

[15] Wisner, A. Por dentro do trabalho: ergonomia método e técnica. São Paulo: FTD/Oboré.1987.

[16] Wisner, A. A inteligência no trabalho: textos selecionados de ergonomia. São Paulo: Fundacentro. 1994
[17]Zaoual, H..Nova economia das iniciativas locais: uma introdução ao pensamento pós-global. Rio de Janeiro: DP\&A Editora,2006.

\section{Fomentation:}

CNPq, PROEXT MEC-SESU, PROEX-UFRN, Bolsas de mestrado CAPES e CNPq, Iniciação Científica CNPq e PROPESQ e, extensão PROEX-UFRN 